\title{
Adventures in Reading
}

\author{
by Jesse Jackson*
}

I think most of us have experienced the thrill of discovery in a pleasing story: the high feeling that comes from exploring a good book; touring through the pages, chapter by chapter; the staking out of a claim with a certain author; having longdrawn out, love affairs with our favorite author's characters; and finally storing up the treasures we remember from certain books - all these adventures came our way with no more effort than stopping at the corner library and applying the seat of our pants to the seat of a chair.

These adventures in reading have been summed up by famous authors themselves. Take the case of John Keats when he first began reading Chapman's translation from the Greek to the English of Homer's Illiad. And here are his words:

*An address delivered at Biennial School Media Work Conference of the North Carolina Association of School Librarians and the Educational Media Association in cooperation with the State Department of Public Instruction on October 31-November 2, 1974.

\section{On First Looking Into Chapman's Homer}

Much have I travell'd in the realms of gold, And many goodly states and kingdoms seen; Round many western islands have I been

Which bards in fealty to Apollo hold.

Oft of one wide expanse had I been told That deep-brow'd Homer ruled as his demesne; Yet did I never breathe its pure serene

Till I heard Chapman speak out loud and bold:

Then felt I like some watcher of the skies When a new planet swims into his ken;

Or like stout Cortez when with eagle eyes $\mathrm{He}$ star'd at the Pacific-and all his men

Look'd at each other with a wild surmiseSilent, upon a peak in Darien.

Or let us take another adventure from reading of a higher order. The case of Samuel Taylor Coleridge. Mr. Coleridge began reading Purchase's travels to the Orient one day many years ago when very little was known about China and the so-called mysterious East. After reading the travel book, Coleridge fell asleep and dreamed a poem line by line. When he 
roused himself from sleep he set down the poem that came to him in a dream brought about by reading a book. And here are lines from this poem:

In Xanadu did Kubla Khan

A stately pleasure-dome decree:

Where Alph, the sacred river, ran

Through caverns measureless to man

Down to a sunless sea.

So twice five miles of fertile ground

With walls and towers were girdled round:

And there were gardens bright with sinuous rills,

Where blossomed many an incense-bearing tree;

And here were forests ancient as the hills,

Enfolding sunny spots of greenery.

And why did he not finish writing one of the most famous poems in the English language? Someone knocked at his door before he could write all the lines he had dreamed of. And he never remembered the rest of the poem and the man who interrupted his recalling goes down in history as the most cursed man in English Literature, or so the story goes.

But adventures in reading were not restricted to the well-born and well-educated man. There were black men in this country long before the Civil War whose imaginations were fired by word-magic. They had been brought to these shores without schooling, and some say without a grammar to their language. But words cast their spell on them. On most plantations there was a Black who knew something about words. They called him the Word Man. Other Blacks who worked close to the "Man" in his big house listened carefully to the conversations of the owner. They listened while he read the newspaper to his wife. They memorized the words they knew nothing about and carried them to the Word Man who listened and pieced the strange words together and told the others what these words meant. Especially if the words had to do with freedom.

The Word Man was an important man at the Hush Harbor, that secret meeting Blacks held at night, deep in the woods out of earshot of the patrollers. The Word Man at the Hush Harbor began the first stirring among Blacks for freedom in the New World.

And there were some Blacks who went a step farther with words into adventures in reading. Men like Gustavus Vassa. Brought to these shores a mere teenager, Vassa wanted to learn to read. He had heard his owner read from a book, and Vassa held the book to his ear hoping that the words would read themselves to him. Failing this he set about picking the words apart and teaching himself to read. Then he hired himself out in spare time from slave tasks and earned enough money to buy his freedom. He went to England. There he wrote a book about his experiences as a slave. This book became a best seller and moved the English Parliament to begin the movement which ended with the freeing of their bondsmen in 1833 .

Another such man was North Carolina's own John Chavous. Born a slave in Virginia, John Chavous' owner sent him to Princeton on a wager with another slave-owner. The wager was: could a slave learn from books? or such education as Princeton offered shortly after the Revolutionary War. John Chavous had fought in the War for Independence. You might say this wager was the Black's GI benefit. Anyhow Chavous taught himself to read before attending Princeton, was graduated with honors, became a minister, and preached successfully in Virginia until the repressive laws following the Nat Turner Rebellion caused Chavous to flee to North Carolina where he built a preparatory school for well-to-do-whites. During the day he taught whites; and Blacks at night. Chavous' papers, I am told, are preserved in a North Carolina college close by.

Another man, Frederick Douglass, excluded from school as a child, living under laws prohibiting a Black from even owning a book or writing material, had his own method of learning to read. His was another stirring adventure in reading. As a 


\section{BROADFOOT'S}

BOOKMARK

\section{NORTH CAROLINA}

BOOKS

WITH

FREE CATALOG CARDS

Prompt service, no backorders. Catalog listing 600 titles on request.

\section{BROADFOOT'S BOOKMARK}

\section{P. O. Box 729}

Wendell, N. C. 27591
By de mercy of de Lord a think happened. I got a roomfeller - he was a slave, too and he had learned to read. In de dead of de night he give me lessons outen de New York Spellin Book. It was hard pullin, I tell you; harder on him, for he know'd just a little and it made him sweat to try to beat somethin into my hard head. It was worse with me. Up de hill every step, but when I got de light of de lesson into my noodle I fairly shouted, but I know'd I was not a scholar. De consequence was I crept long mighty tedious, gittin a crumb here and dere until I could read de Bible by skippin de long words, tolerable well. Dat was de state of my education - dat is what little I got. I make mention of dat young man. De years have fled away since den but I ain't forgot my teacher and never shall. I thank my Lord for him and I carries his memory in my heart.

Bout seven months after my gittin to readin, God converted my soul and I reckon bout de first and main thing dat I begged de Lord to give me was de power to understand $\mathrm{His}$ Word. I ain't braggin and I hates self-praise, but I bound to speak de thankful word. I believes in my heart dat my prayer to understand de Scriptur was heard. Since dat time I ain't cared bout nothin 'cept to study and preach de Word of God.

Not, my brothern, dat I's de fool to think I knows it all. Oh, my Father, no! Far from it. I don't hardly understand myself nor half of de things round me and dere is millions of things in de Bible too deep for Jasper and some of 'em too deep for everybody. I don't carry de keys to de Lord's closet and $\mathrm{He}$ ain't tell me to peep in and if I did I'm so stupid I wouldn't know it when I see it. No, friends, I knows my place at de feet of my Master and dere I stays.

But I can read de Bible and get de things what lay on de top of de soil. Outen de Bible I know nothin extry bout de sun. I seen its course as he rides up dere so gran and mighty in de sky, but dere is heaps about dat flamin orb dat is too much for me. I know dat de sun shines powerfully and pours down its light in floods and yet dat is nothin compared with de light dat flashes in my mind from de pages of God's book. But you knows all dat. I knows dat de sun burns - oh, how it did burn in dem July days! I tell you he cooked de skin on my back many a day when I was hoein in de corn field. But you knows all dat - and yet dat is nothin to de divine fire dat burns in de souls of God's chillun. Can't you feel it, Brothren?

We have many such accounts. I could not resist digging into one more testimony. That from another Tarheel self-taught poet whose poems were published in Raleigh
Low me to say dat when 1 was a young man concerning books. Dey was sealed mysteries to me, but I tell you I longed to break de seal. I thirsted for de bread of learnin. When I seen books I ached to git in to 'em for I knowed dat dey had de stuff for me and I wanted to taste dere contents, but most of de time dey was barred against me. 
before the end of the Civil War. Some of his poetry was written for Chapel Hill students who paid him twenty-five cents a poem. They probably did not remember to mention the source of their poetry when they sent it to their loved ones.

Of his known published work the following is my favorite.

\footnotetext{
"Black I am, oh! daughters fair!

But my beauty is most rare.

Black, indeed, appears my skin,

Beauteous, comely, all within:

Black when by affliction press'd,

Beauteous, when in Christ I rest;

Black, by sin's defiling blood;

Beauteous, washed in Jesus' blood;

Black I am in my own eyes,

Beauteous in my Lord's I rise

Black I am to men, ' $t$ is true

Beauteous in the angel's view

Black, if Jesus frowns a while,

Beauteous, when I see him smile;

Black, while in the tomb I lie,

Beauteous, when I mount the sky."
}

The poet was self-educated. Of his struggle to learn to read he said:

\begin{abstract}
".. Hence I had to sit sweating and smoking over my incompetent bark of brush light, almost exhausted by the heat of the fire, and almost suffocated with smoke, consequently from Monday morning I anticipated with joy the approach of the next Sabbath, that I might again retire to the pleasant umbrage of the woods, whither 1 was used to dwell or spend the most of the day with ceaseless investigation over my book. A number strove to dissuade me from my plan, and had the presumption to tell me that I was a vain fool to attempt learning to read with as little chance as I had. . . ."
\end{abstract}

George Moses Horton, the poet, was born a slave in 1797 . He lived until 1880 .

The men I have mentioned and their various adventures in reading have one thing in common. A thing that linked them together whether they were white, black, free, poor, rich or handsome. They were bound together like the pages of a book are bound together by a bookbinder. What bound them together was their cour- age to seek adventure inside the covers of a book.

Now I want to speak about some of our young who somehow or other failed to be touched by this call to adventure. Here is an account of one such lad taken from a 1973 issue of the NEW YORK TIMES:

\section{Poor Reader Sues Coast Educators}

\section{Boy Asks \$ Million Damages from California System}

SAN FRANCISCO, Sept. 16. Peter W. Doe is an 18 year-old boy from a middle-class family. Throughout his school years he attended class regularly, caused no disciplinary problems and got his high school diploma on schedule.

But Peter W. Doe- not his real namewas unable to read at a level beyond fifth grade. He could not understand applications and and was afraid to take a salesman's job because of the paperwork involved.

Now, nearly two years after graduation, Peter is the plaintiff in a \$1-million damage suit against the San Francisco Unified School District and state officials who allowed him to graduate without proper reading skills.

Authorities say Peter is only one of thousands of youngsters with a similar problem.

\section{Problem For Almost Half}

Ruth Love Holloway, director of the United States Office of Education's Right to Read program, estimated recently that 40 to 50 percent of the pupils in larger cities have reading problems.

Federal statistics indicate that 19 million Americans over the age of 16 are, like Peter, unable to comprehend job applications, drivers' license manuals or bank loan questionnaires.

Most of those who cannot read at an adult level drop out of school. But some experts estimate that several thousands graduate each year without proper reading skills.

Harriet Doe said her son was not aware of his problem until after he had finished school. 
"Then he realized there were little ordinary things he couldn't do," Mrs. Doe said. "He was so embarrassed when he couldn't read or comprehend job applications."

Peter wanted to work as a clothing salesman, but he was shaken by the prospect of paperwork. He took $a$ job as an instrument boy with a band.

The suit says that when Peter received his diploma in January, 1972, his reading level made him "unqualified for employment other than the demeaning, unskilled, low-paid labor." It contends that under California law the state is responsible for minimum educational standards and for establishing a system that turns out pupils with these skills.

What happened to such young people whose numbers are ever growing in our midst at a time when it is no longer necessary to steal away and hide in the woods to read a book? There are many reasons for what has happened and I would rather spend the time I have talking about the remedy rather than the wrong. Let us dwell on the news story and what it so eloquently brings out which is: The key to education for living, for the new educational and career opportunities is reading. It is essential that youth begin a program of voluntary reading in the elementary school. It is impossible to get all the knowledge and skills needed for living in today's world through complete dependence on instruction in the classroom and out of textbooks. It is more and more apparent that our young should be encouraged to read a wide range of materials in order to get the educction needed to compete. Recently a young friend of mine took an examination to enter one of the finest medical schools in New York. He passed with flying colors. I asked him what the exam was based on and he told me that anyone who had read the NEW YORK TIMES daily could have passed the exam. In fact he had been reading the NEW YORK TIMES in his school library.

The elementary school library can offer valuable services to improve the reading skills of our young. They can do this by providing reading materials of greater interest than textbooks, supplementing the teacher's work, especially now with the advanced tools of educational mediathe sixteen millimeter film, film strip, audiovisual programs and modern-day marvels.

I want to dwell on the remedies and not on the wrongs. The school library is there to help the child extend his speaking and reading vocabulary. Of course, there must be a concerted effort not only by teachers, librarians, media specialists, guidance counselors, and parents to encourage children to dare the adventures of reading. And of course if children see their parents reading a book it helps win them over.

Appalachian State University's College of Education has added another incentive to tempting children to the highway of reading adventure with their Visiting Author Program. I have been privileged to take part in this program. The Visiting Author goes to schools, school libraries, and classrooms telling stories and talking about books, sometimes the author's own books, sometimes books in general. Through these personal appearances the author tries to fire the students' interest in reading.

And here if you will pardon my reference to the personal I should like to share with you some of my adventures in reading. An older sister took me to a library when I was seven. From that time I have 
been hooked by books. From that time I have enjoyed the company of great storytellers. It meant that such formal education as I received was a lark because usually I had had the good fortune to have been introduced to my classroom subjects from reading. My published works have been the direct result of my adventures in reading. A small attempt on my part to repay others for the pleasure I got from reading.

The public library brought me $\$ 32,000$. I should add, the momentary possession, of $\$ 32,000$ all in one lump. This is the way that happened. I had been reading micro-films of Horace Greely's 1863 TRIBUNE and ordered photo-stats of some of the issues that amounted to $\$ 32$. I asked my bank for a cashiers check for $\$ 32$. The bank clerk gave me a check for $\$ 32,000$ which I took to the library without noting the mistake. Later the librarian called me to come and pick up the check, saying that I had overpaid them. I returned the check to the bank. They corrected the mistake. For one day of my life I owned $\$ 32,000$ all in one lump.

Another compelling reason children should be brought early to reading adventures in our libraries is this. When they grow up and decide to prepare for federal, state, county, or city civil service examinations - where do they have to go to find out about such examinations? To the library where trained librarians help in all cases.

Let me end this talk with still one more adventure in reading. On a recent visit to the Library Science Department of North Carolina Central University, I discovered the poetry of a member of the faculty,
Miss Mary Bohanon. Here is one of her sonnets from her Earth Bosom and Collected Poems:

\section{Sonnet To My Grandfather}

I have no quarrel with life but simply

This, that being Black most things come too late.

Being denied Man's opportunity,

And fighting to o'ercome my destined fate

That made me as I am, scorched, chained, unfree Of body, but soul intact to worship.

The Great Ship lowers its mast, beckons me,

And I am sore to go without the whip

So accustomed am I to being urged,

Not by the strap, but by my will to live.

Unnamed, unwanted, auctioned I have surged

Above the surface only to survive.

I have come tardy, despite skin cover.

It is too late, too soon, and all over.

\section{FACTS ABOUT FACS}

Fact 1: FACS stands for Faxon's Automated Claim System

Fact 2: FACS is a new automated system intended to make life a lot easier for you.

Fact 3: To place a claim, all you do is complete and return our claim notice form. We then activate our computer to process the claim to the publisher with complete order and payment information included.

Fact 4: You receive a quarterly report of all your claim request activity.

Fact 5: This is only one reason. among many, why you should choose Faxon, the world's only fully automated library magazine subscription agency. For particulars, write for a copy of our Service Brochure and annual Librarians' Guide to Periodicals. Or call toll-free: 1-800-225-7894.

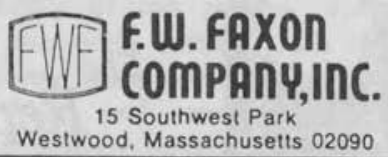




\section{Our 1976 Reprints}

Battle, Kemp P.

HISTORY OF THE UNIVERSITY OF NORTH CAROLINA.

(1907-12) 2 v., $1,840 \mathrm{pp}$.

$\$ 60.00$

Berney, Saffold

HAND-BOOK OF ALABAMA. (1892) 568 pp.

$\$ 24.00$

Brewer, Willis

ALABAMA: HER HISTORY, RESOURCES, WAR RECORD, AND PUBLIC MEN.

FROM 1540 TO 1872 . (1872) $712 \mathrm{pp}$

$\$ 2700$

Callcott, W. H. (Ed.)

SOUTH CAROLINA: ECONOMIC AND SOCIAL CONDITIONS IN 1944

(1945) $248 \mathrm{pp}$.

DeLeon. Thomas $C$

FOUR YEARS IN REBEL CAPITALS. (1890) $392 \mathrm{pp}$.

15.00

Derrick, Samuel $M$.

CENTENNIAL HISTORY OF THE SOUTH CAROLINA RAILROAD

(1930) $442 \mathrm{pp}$.

Federal Writers' Project

PALMETTO PLACE NAMES. $11941,160 \mathrm{pp}$

Garrett, William

REMINISCENCES OF PUBLIC MEN IN ALABAMA. (1872) $816 \mathrm{pp}$.

\section{$\$ 18.00$}

$\$ 21.00$

$\$ 10.50$

$\$ 30.00$

Hodgson, Joseph

THE CRADLE OF THE CONFEDERACY: OR, THE TIMES OF TROUP.

QUITMAN AND YANCEY. (1876) $544 \mathrm{pp}$

21.00

Hough, Franklin B. (Ed.

THE SIFCE OF CHARLESTON $(1867,226 \mathrm{pp}$

THE SIEGE OF SAVANNAH. (1866) $190 \mathrm{pp}$

Irving, John $B$.

THE SOUTH CAROLINA JOCKEY CLUB. (1857) $260 \mathrm{pp.}$

Jack, Theodore $H$

SECTIONALISM AND PARTY POLITICS IN ALABAMA 1819-1842. (1919) 104 pp. \$10.50

Kohn. August

THE COTTON MILLS OF SOUTH CAROLINA. (1907) 228 pp.

$\$ 12.00$

Lee, Henry

THE CAMPAIGN OF 1781 IN THE CAROLINAS, (1824) 562 pp.

$\$ 21.00$

Leiding, Harriette $K$.

HISTORIC HOUSES OF SOUTH CAROLINA. (1921) $542 \mathrm{pp}$

$\$ 2400$

Meek. Alexander $B$

ROMANTIC PASSAGES IN SOUTHWESTERN HISTORY. (1857) $336 \mathrm{pp}$.

$\$ 1500$

O'Neall. John B.

BIOFRAPHICAL SKETCHES OF THE BENCH AND BAR OF SOUTH CAROLINA

(1859) 2 v.. $1,090 \mathrm{pp}$.

Petty, Julian $J$.

THE GROWTH AND DISTRIBUTION OF POPULATION IN SOUTH CAROLINA

(1943) 242 pp., 81/" X $11^{\prime \prime}$

Pickett, Albert $J$, and Owen, Thomas $M$.

HISTORY OF ALABAMA AND INCIDENTALLY OF GEORGIA AND

MISSISSIPPI with the ANNALS OF ALABAMA $1819-1900 \ldots$ (1900) $784 \mathrm{pp}$

Seals. Monroe

HISTORY OF WHITE COUNTY. TENNESSEE. (1935) $168 \mathrm{pp}$.

$\$ 45.00$

Smith. William $R$.

THE HISTORY AND DEBATES OF THE CONVENTION OF THE PEOPLE OF ALABAMA, 1861, $480 \mathrm{pp}$

We Have Over 200 Titles Available on The Southeastern Region and Are Always Expanding That List Write For Complete Catalogue.

\section{The}

\section{Reprint Company, Publishers}

